\title{
The Ischemic Immature Brain: Views on Current Experimental Models
}

\author{
Tânia Faustino-Mendes ${ }^{1}$, Marta Machado-Pereira ${ }^{1,2}$, Miguel Castelo-Branco ${ }^{1,2,3}$ and \\ Raquel Ferreira ${ }^{1,2 *}$ \\ ${ }^{1}$ Faculty of Health Sciences, University of Beira Interior, Covilhã, Portugal, ${ }^{2}$ Health Sciences Research Centre (CICS-UBI), \\ University of Beira Interior, Covilhã, Portugal, ${ }^{3}$ Hospital Center of Cova da Beira, Covilhã, Portugal
}

Keywords: perinatal, neonatal, stroke, experimental models, immature brain

\section{STROKE IN PRETERM AND TERM NEWBORNS}

Perinatal stroke occurs between the 20th week of gestation and the 28th day after birth (Nelson, 2007). Brain injury within this period can also lead to conditions such as neonatal encephalopathy or to encephalopathy of prematurity. Considering the complex diagnosis and limited data available, the incidence of 1/2,300 live births is a likely underestimation (Nelson and Lynch, 2004; Lee et al., 2005). Nevertheless, these numbers are comparable to those in the elderly (Fernández-López et al., 2014). The most common subtypes are arterial ischemic stroke (Fernández-López et al., 2014), which induces a focal lesion similar to adult stroke, and cerebral sinovenous thrombosis (Govaert et al., 2009). Focal interruption of arterial or venous cerebral blood flow is usually secondary to thrombosis or embolism, with a multifactorial pathophysiology. Importantly, in the fetal circulatory system, placental or systemic venous emboli may pass through a patent ductus arteriosus or foramen ovale directly to the left carotid artery and subsequently to the left MCA, facilitating occlusion (Gunny and Lin, 2012). Confirmation by imaging or neuropathological

OPEN ACCESS

Edited by:

Sikha Saha,

University of Leeds, United Kingdom

Reviewed by:

Marta Fumagalli,

Università degli Studi di Milano, Italy

Marco Bacigaluppi,

San Raffaele Scientific Institute

(IRCCS), Italy

*Correspondence:

Raquel Ferreira

raquelmargarida@gmail.com

Received: 25 March 2018 Accepted: 08 August 2018

Published: 29 August 2018

Citation:

Faustino-Mendes T,

Machado-Pereira $M$,

Castelo-Branco $M$ and Ferreira $R$

(2018) The Ischemic Immature Brain:

Views on Current Experimental

Models. Front. Cell. Neurosci. 12:277. doi: 10.3389/fncel.2018.00277 studies is always mandatory (Govaert et al., 2009). Different risk factors have been recognized for perinatal stroke (Supplementary Table 1; Kurnik et al., 2003; Mirabelli-Badenier et al., 2012; Kasdorf and Perlman, 2013; Basu, 2014; Fernández-López et al., 2014; Kratzer et al., 2014; Machado et al., 2015; Buerki et al., 2016) but inflammation seems to be a prevalent underlying mechanism (Vexler and Yenari, 2009; Hagberg et al., 2015). For instance, chorioamnionitis, a bacterial infection of the amniochorionic membranes (Kasdorf and Perlman, 2013; Buerki et al., 2016) often leads to a longer labor period and worse prognosis (Vexler and Yenari, 2009). Nevertheless, although there is a substantial number of studies concerning neonatal encephalopathy (or hypoxic-ischemia encephalopathy), human data on perinatal stroke can be disparate; some authors found a positive correlation with pro-inflammatory polymorphisms, others did not (Hagberg et al., 2015).

Adult and perinatal stroke also cause distinct presenting symptoms: adults tend to present unilateral symptoms and only $3 \%$ have seizures; seizures are one of the most common presentations after perinatal stroke (Fernández-López et al., 2014). Hemiplegic cerebral palsy is also the most frequent long-term motor outcome of the latter (Nelson, 2007). However, several aspects delay the suspicion of diagnosis, since (i) newborns with seizures may appear clinically well-between episodes; (ii) initially, newborns may present discrete non-specific symptoms like lethargy, apnea, difficult feeding and impaired chewing; (iii) and some cases may be asymptomatic, presenting lateralized symptoms only around the 5th month. In fact, lateralized symptoms are rare in neonates (Nelson, 2007; Fernández-López et al., 2014). In 2011, Harbert and colleagues conducted the first human study demonstrating the positive effect of therapeutic hypothermia on perinatal stroke: active whole-body cooling via a blanket cooling device led to a significantly lower frequency of seizures (Harbert et al., 2011). Since these symptoms are associated to a worse prognosis, the risk of long-term neurologic disability is likely reduced. Given the complex pathophysiology and difficulty in obtaining an early and accurate diagnosis, new therapies are being tested, alone 
or in combination with hypothermia, to improve global outcome. Some include administration of growth factors, anticoagulant and antiplatelet agents, blood uric acid lowering medication, antioxidant and anti-inflammatory molecules, stem cells-based therapy and electrical stimulation (Cnossen et al., 2009; Gonzalez and Ferriero, 2009; Mirabelli-Badenier et al., 2012; Basu, 2014; Fernández-López et al., 2014; Kratzer et al., 2014).

\section{IN VITRO APPROACHES}

In vitro models resort to oxygen and glucose deprivation (OGD), followed by reoxygenation and nutrient replenishment. Since oxygen levels should be kept preferably under $2 \%$, to represent the ischemic core, and around $7 \%$ if studying the ischemic penumbra (Tornabene and Brodin, 2016), these models can be very relatable while allowing easy assessment of cell activity, protein expression and release, and barrier properties of particular cell type(s). We have exposed either individualized cells or brain tissue, namely organotypic brain slice cultures (OSC), to very low $\mathrm{O}_{2}$ rates (0.1\%; Ferreira et al., 2016; MachadoPereira et al., 2017). These tissue cultures provide unique characteristics and several advantages over cell models, since they preserve whole organ structure and maintain neuronal activity and synapse circuitry. OSC also maintain integrity in vitro for over 2 weeks allowing a series of pharmacological studies. Other advantages include the possibility of using younger animals if needed (e.g., 1-3-day-old mice), the refinement of experimental doses/conditions and the reduction of the number of animals for in vivo models. To the best of our knowledge only one group has used OSC, from P8-10 rats (Leonardo et al., 2009). A considerable drawback from OSC, and cell cultures, is the absence of blood flow and infiltrating immune cells. Nevertheless, they provide a snapshot of the neurovascular unit up to the time of brain isolation if a lesion and/or treatment is applied $a$ priori. Younger animals such as 2-day-old mice still grant the ability to inject a therapeutic agent via the temporal vein, which is still visible at this age, to study its protective value (Machado-Pereira et al., 2018). Subsequently, therapeutic agents and stimuli can be further administered over tissue to evaluate their impact on neurovascular and glial activity.

\section{ANIMAL MODELS OF PERINATAL STROKE}

Experimental models are important to understand mechanisms of disease. Parameters like injury onset and duration, area of penumbra, reperfusion or therapeutic window are clearly defined, and symptoms can be easily identified and monitored. However, reproducing all the complex pathophysiological aspects of stroke in an otherwise healthy animal is challenging; typically, a stroke patient is elderly and has more than one health condition. One of the most frequently used adult models is induced by transient occlusion of the middle cerebral artery (MCA) with an intraluminal monofilament, blocking cerebral blood flow (usually $60 \mathrm{~min}$ ) and causing reproducible infarcts in this territory (Carmichael, 2005; Sommer, 2017). A transient model allows the study of the significant effects of reperfusion.
Regarding the perinatal period, the most common methodologies use unilateral ligation of the common carotid artery followed by hypoxia, or direct exposure to hypoxia alone. Table 1 briefly describes procedures using rodents, rabbits, pigs and lambs. Animal models employing pigs, lambs or rabbits, are costly in terms of maintenance, in the sense that they have longer gestation periods and smaller litter size, while offering higher genetic dissimilarity with humans, comparing with mice (Leong et al., 2015). Importantly, most models use $\mathrm{O}_{2}$ rates much higher (5-12\%) than those believed to occur after an ischemic event. Only one group used a lower percentage (3.5-4\%), albeit on rats of an age range comparable to a term and up to 2-years-old infant. In fact, normal brain tissue $\mathrm{pO}_{2}$ is $33.8 \pm 2.6 \mathrm{mmHg}$, which corresponds to $4.4 \pm 0.3 \% \mathrm{O}_{2}$ in the microenvironment (Carreau et al., 2011). Three of the models used between 6 and $12 \% \mathrm{O}_{2}$ : a fraction of inspired oxygen $\left(\mathrm{FiO}_{2}\right)$ of 0.06-0.12. Considering that atmospheric air is $21 \% \mathrm{O}_{2}$ or the equivalent to a $\mathrm{FiO}_{2}$ of 0.21 , these animals would be subjected to a third to a half $\mathrm{O}_{2}$ available. Are lower $\mathrm{O}_{2}$ rates fatal? Moreover, most models use 7-days-old or older animals, which offer a more reasonable size for surgery than younger pups. A week old rat, the most commonly used species, would represent a 2-months-old infant (well-beyond the 28th day post-birth) if considering peripheral organ systems (Sengupta, 2013; Titomanlio et al., 2015), and a term infant, if considering brain development (Titomanlio et al., 2015), raising further challenges on what age range to choose.

Age is very important, since the extent of ischemic injury is largely influenced by brain maturity (Sheldon et al., 1996; McQuillen et al., 2003; Webber et al., 2009). In preterm newborns, oligodendrocyte progenitor cells (OPC) are particularly more sensitive to ischemia (Back et al., 2002). Global ischemia, as in hypoxic-ischemia encephalopathy, disrupts OPC maturation, causing delayed or disrupted myelination, largely contributing to neuronal loss and periventricular white matter diffuse injury (periventricular leukomalacia; Back et al., 2007; Webber et al., 2009). Several experimental models have also been proposed to study this particular condition (Shen et al., 2010). For this reason, OPC constitute a potential target for the development of protective therapies focusing on the reduction of white matter loss in premature infants (Back et al., 2007). Subplate neurons, a transient neuronal population important for the formation of mature neuronal networks, are another vulnerable target. Additionally, interneuron migration to the neocortex is only completed at birth, in a process modulated by microglia activity (Leviton and Gressens, 2007; Xu et al., 2011). In term newborns, gray matter is focally affected, greatly impacting on motor function (Back et al., 2001; FernándezLópez et al., 2014; Luhmann et al., 2016). The immature brain is also more susceptible to excitotoxicity and to free radicals considering the higher expression of receptors that signal for excitatory neurotransmitters and lower levels of anti-oxidant enzymes (Johnston, 2005; Lafemina et al., 2006). Overall, choosing the "right" age pertains to the fact that the perinatal period encompasses different stages of the circulatory and immune systems (Titomanlio et al., 2015; Lange et al., 2016). Accordingly, the therapeutic value of an agent directed at 
TABLE 1 | Perinatal and neonatal animal models for ischemic injury, specifically rat, pig, mouse, rabbit, and lamb.

\begin{tabular}{|c|c|c|}
\hline \multicolumn{3}{|l|}{ RAT } \\
\hline P5-P17 Ф & $\begin{array}{l}\text { Exposure to hypoxia }\left(3.5-4 \% \mathrm{O}_{2} \text { in } \mathrm{N}_{2}\right) \text { until apnea or heart rate below } 20 \% \text { of } \\
\text { baseline }\end{array}$ & Jensen, 1995 \\
\hline $\mathrm{P} 10 \Phi$ & Exposure to hypoxia $\left(7,5,4 \% \mathrm{O}_{2}\right.$ in $\left.\mathrm{N}_{2}\right)$ for 8,6 , and $1 \mathrm{~min}$, respectively & Dunn et al., 2017 \\
\hline P10 $\Phi$ & $\begin{array}{l}\text { Left MCAO for } 90 \text { min by inserting a } 6-0 \text { nylon filament into the internal carotid artery; } \\
\text { unilateral ligation of right CCA followed by hypoxia }\left(8 \% \mathrm{O}_{2} \text { in } \mathrm{N}_{2}\right) \text { for } 90 \text { min }\end{array}$ & Ashwal et al., 2007 \\
\hline P7 우 & MCAO for 180 min by inserting a $6-0$ coated filament into the internal carotid artery & Fernández-López et al., 2013 \\
\hline P7 $\Phi$ & Unilateral ligation of right CCA followed by hypoxia $\left(8 \% \mathrm{O}_{2}\right.$ in $\left.\mathrm{N}_{2}\right)$ for $60 \mathrm{~min}$ & Jantzie and Todd, 2010 \\
\hline P7 $\Phi$ & Unilateral ligation of CCA followed by hypoxia $\left(8 \% \mathrm{O}_{2}\right.$ in $\left.\mathrm{N}_{2}\right)$ for 30,60 , 90 , or $120 \mathrm{~min}$ & Silverstein and Johnston, 1984 \\
\hline P7 $\Phi$ & Unilateral ligation of left CCA followed by hypoxia $\left(8 \% \mathrm{O}_{2}\right.$ in $\left.92 \% \mathrm{~N}_{2}\right)$ for 90 min & Bae et al., 2012 \\
\hline P7 $\Phi$ & Unilateral ligation of right CCA followed by hypoxia $\left(8 \% \mathrm{O}_{2}\right.$ in $\left.\mathrm{N}_{2}\right)$ for $180 \mathrm{~min}$ & Jantzie et al., 2005 \\
\hline P7 $\Phi$ & Unilateral ligation of left CCA followed by hypoxia $\left(8 \% \mathrm{O}_{2}\right.$ in $\left.\mathrm{N}_{2}\right)$ for 120 min & Lubics et al., 2005 \\
\hline P7 $\Phi$ & Unilateral ligation of CCA followed by hypoxia $\left(8 \% \mathrm{O}_{2}\right.$ in $\left.\mathrm{N}_{2}\right)$ for $60-240$ min & Vannucci and Vannucci, 2005 \\
\hline P4 ס & Exposure to hypoxia $\left(11 \% \mathrm{O}_{2}\right.$ in $\left.\mathrm{N}_{2}\right)$ for 360 min per day for 5 days & Schaeffer et al., 2013 \\
\hline P4 $\Phi$ & Exposure to hypoxia $\left(11 \% \mathrm{O}_{2}\right.$ in $\left.\mathrm{N}_{2}\right)$ for 360 min per day for 5 days & Fendt et al., 2008 \\
\hline $\mathrm{P} 2 \Phi$ & Exposure to hypoxia $\left(12 \% \mathrm{O}_{2}\right.$ in $\left.\mathrm{N}_{2}\right)$ for 14 days & Deruelle et al., 2006 \\
\hline P1 ठ & Exposure to hypoxia $\left(12 \% \mathrm{FiO}_{2}\right)$ for 10 days & Del Duca et al., 2009 \\
\hline$P 1 \Phi$ & Unilateral ligation of right CCA followed by hypoxia $\left(8 \% \mathrm{O}_{2}\right.$ in $\left.\mathrm{N}_{2}\right)$ for $210 \mathrm{~min}$ & Girard et al., 2009 \\
\hline P1 $\Phi$ & Exposure to hypoxia $\left(5 \% \mathrm{O}_{2}\right.$ in $\left.\mathrm{N}_{2}\right)$ for 60 or $75 \mathrm{~min}$ & Slotkin et al., 1995 \\
\hline Newborn o $\sigma^{x} / q$ & Unilateral ligation of right CCA followed by hypoxia $\left(8 \% \mathrm{O}_{2}\right.$ in $\left.\mathrm{N}_{2}\right)$ for $120 \mathrm{~min}$ & Kartal et al., 2016 \\
\hline \multicolumn{3}{|l|}{ PIG } \\
\hline P3-P7 Ф & $\begin{array}{l}\text { Exposure to a gas mixture }\left(10 \% \mathrm{FiO}_{2}\right) \text { for } 40 \text { min, followed by } 5 \text { min of reoxygenation } \\
\text { and } 7 \text { min of anoxia by clamping the endotracheal tube }\end{array}$ & Ni et al., 2011 \\
\hline P1-P4 o & $\begin{array}{l}\text { Exposure to a gas mixture }\left(\mathrm{FiO}_{2} 6-8 \%\right) \text { until hearth rate decreased to } 60 \text { beats/min } \\
\text { (bradycardia) or mean arterial blood pressure decreased to } 15 \mathrm{mmHg} \text { (severe } \\
\text { hypotension) }\end{array}$ & Faa et al., 2012 \\
\hline P1-P3 $\Phi$ & 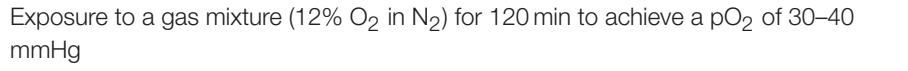 & Stevens et al., 2008 \\
\hline Newborn $\Phi$ & $\begin{array}{l}\text { Exposure to a gas mixture }\left(8 \% \mathrm{O}_{2} \text { in } \mathrm{N}_{2}\right) \text { until the mean arterial blood pressure } \\
\text { decreased to } 20 \mathrm{mmHg} \text { or base excess reached }-20 \mathrm{mmol} / \mathrm{L}\end{array}$ & Garberg et al., 2017 \\
\hline \multicolumn{3}{|l|}{ MOUSE } \\
\hline P9 $\Phi$ & Unilateral ligation of left CCA followed by hypoxia $\left(10 \% \mathrm{O}_{2}\right.$ in $\left.\mathrm{N}_{2}\right)$ for $60 \mathrm{~min}$ & Kichev et al., 2014 \\
\hline P7 ס & $\begin{array}{l}\text { Exposure to hypoxia ( } 10 \% \mathrm{O}_{2} \text { in } \mathrm{N}_{2} \text { ) for } 360 \text { min per day ( } 3 \text { sessions of } 120 \text { min } \\
\text { separated by } 45 \text { min intervals) for } 6 \text { days }\end{array}$ & Kameda et al., 2013 \\
\hline \multicolumn{3}{|l|}{ RABBIT } \\
\hline E22 $\Phi$ & $\begin{array}{l}\text { Uterine ischemia for } 40 \text { min, via arterial embolectomy catheter inserted through the } \\
\text { maternal left femoral artery into the descending aorta }\end{array}$ & Yu et al., 2011 \\
\hline \multicolumn{3}{|l|}{ LAMB } \\
\hline E126-141 $\Phi$ & $\begin{array}{l}\text { Intrauterine hypoxia by induced maternal hypotension via infusion of trimetaphan } \\
\text { camsylate glucose solution into a polyethylene catheter placed in the maternal } \\
\text { femoral vein, for } 60-90 \mathrm{~min}\end{array}$ & Gersony et al., 1976 \\
\hline
\end{tabular}

Rodent models usually resort to exposure to hypoxia alone $\left(3.5-12 \% \mathrm{O}_{2}\right)$ or to unilateral ligation of the common carotid artery, followed by hypoxia (8\% $\left.\mathrm{O}_{2}\right)$, in animals of varying ages.

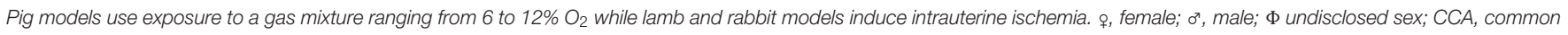
carotid artery E, embryonic days; MCAO, middle cerebral artery occlusion; min, minutes; P, post-natal days.

perinatal stroke would be better assessed using younger animals. Fundamentally, the brain vasculature during development is formed through two distinct processes: (i) vasculogenesis, in which angioblasts differentiate into endothelial cells forming the perineural vascular plexus, which in turn functions as a substrate for (ii) angiogenesis, the process of generating new vessels from pre-existing ones (Vasudevan and Bhide, 2008; Lee et al., 2009; Tam and Watts, 2010). These processes are consolidated by migrating mural cells, formation of an extracellular matrix and establishment of tight and adherens junctions that regulate permeability and transcellular transport (Lee et al., 2009; Tam and Watts, 2010). With increasing age, blood-brain barrier (BBB) functionality is less maintained after stroke since the expression of several of these proteins (e.g., occludin, claudins, zonula occludens proteins; Kratzer et al., 2014) that support the integrity of tight junctions is also changed. Another reason for a higher resistance of the BBB to ischemic injury in the early stages could be the maturation-dependent interplay between leukocytes and the endothelium and the less active pathophysiological role of the inflammatory process (Titomanlio et al., 2015). A restricted BBB opening may also account for limited neutrophil recruitment/infiltration. While regulatory $\mathrm{T}$ 
cells seem to play a neuroprotective role, microglia cells promote phagocytosis and tissue recovery, or white matter damage, depending on the adopted phenotype (Hagberg et al., 2015). In fact, microglia migrate to the brain even before blood vessel formation possibly impacting on the development of these structural elements (Rymo et al., 2011; Arnold and Betsholtz, 2013). Hence, in the perinatal period, the neuroinflammatory response has a preponderant role in stroke outcome (and to diffuse pattern of injury), relying more on the activation of microglia than on the extrinsic recruitment of inflammatory cells such as macrophages and neutrophils (Hagberg et al., 2015). A more mature brain offers a BBB more vulnerable to ischemic injury and to immune cell infiltration, and therefore, these cells assume a greater role and become associated to a focal pattern of injury. Consequently, several pro-/anti-inflammatory molecules and growth factors are released and have been studied as part of the impactful secretome unleashed by ischemia. Vascular endothelial growth factor (VEGF) is responsible for several processes upon ischemic stroke, including disruption of endothelial cell junctions and endothelial cell endocytosis, followed by increased BBB permeability, and consequently intracranial hemorrhage and intracranial hypertension (Angelo and Kurzrock, 2007; Lange et al., 2016; Suzuki et al., 2016). However, VEGF also promotes endothelial cell proliferation and migration, and enhances perfusion (reduced infarct volume and penumbra were associated to increased neuroprotection, including in neonatal stroke; Titomanlio et al., 2015; Lange et al., 2016; Suzuki et al., 2016). There are other cell types responsible for the development, regulation and maintenance of central nervous system angiogenesis and BBB integrity such as pericytes and astrocytes (Tam and Watts, 2010). These cells control the production and release of several factors that regulate the aforementioned processes (Lee et al., 2009; Tam and Watts, 2010; Arnold and Betsholtz, 2013). Therefore, diminished quantities of pericytes and astrocytes alongside blood vessels are associated to a higher susceptibility to ischemic injury (Fernández-López et al., 2014; Kratzer et al., 2014).

On a final note, rodent strains may display different levels of vulnerability to injury. For instance, CD1 mice are more vulnerable to damage induced by $30 \mathrm{~min}$ of hypoxia, than C57BL/6 and 129Sv mice, with the latter being the most resistant strain (Sheldon et al., 1998). Other murine strains (BDF, $\mathrm{CFW}$, and BALB/C) display varying infarct volumes following $24 \mathrm{~h}$ of focal ischemia possibly because of differences in the anatomy of the posterior communicating arteries. BALB/C mice showed a more significant infarct volume and were proposed as the most suitable strain to conduct pharmacological studies in cerebral ischemia (Barone et al., 1993). In addition to differences in vascular anatomy, humans and other animals also display significantly different nutrient and oxygen metabolism, hemodynamics, and neural cell population density/activity (Dirnagl et al., 1999).

An interesting but poorly studied subject is the fact that perinatal stroke appears to be gender-dependent with male neonates and children being more commonly affected and with poorer outcomes (Turtzo and McCullough, 2010; FernándezLópez et al., 2014). Turtzo and McCullough have extensively reviewed the role of gender and sex hormones in the perinatal, infant and adult periods. Although in vitro data from female pups suggest higher protection from OGD, and neuronal cells from males seem more susceptible to hypoxic injury (Heyer et al., 2005; Li et al., 2005), clinical studies and mechanisms of action remain inconclusive. Overall, ischemic cell death occurs via a caspase-independent pathway in males, while this process is caspase-dependent in females; ultimately, both pathways lead to mitochondrial dysfunction. The protection provided by female sex hormones, such as estrogen and progesterone, is a possible explanation. However, estrogen and progesterone administration to post-menopausal women were found to raise the risk of stroke (Turtzo and McCullough, 2010). To further investigate this issue in the perinatal period, it is possible to divide pups, even after birth, by a distinct physical trait: male mice have a visible pigment spot on the scrotum (Wolterink-Donselaar et al., 2009).

\section{CONCLUSIONS}

In vitro models are useful for assessing the potential of a therapeutic agent and constitute an inescapable stepping stone for in vivo models. However, current animal models still hold key limitations regarding the level of hypoxia and extent of focal injury, age and costs associated to the selected animal species/strain, as well as their basic anatomy. Importantly and understandably, all fail to reproduce the exact mechanisms of injury that occur specifically in perinatal stroke. Hence, it is urgent to continue advancing newer (and multifactorial) experimental models to attain more efficient therapies to treat this complex vascular condition and long-term sequela.

\section{AUTHOR CONTRIBUTIONS}

All authors listed have made a substantial, direct and intellectual contribution to the work, and approved it for publication.

\section{FUNDING}

Work supported by FEDER through POCI-COMPETE 2020 (POCI-01-0145-FEDER-007491, FCOMP-01-0124-FEDER041099), and through CENTRO 2020 (CENTRO-01-0145FEDER-000013), Foundation for Science and Technology (UID/Multi/00709/2013, IF/00178/2015/CP1300/CT0001), L'Oréal-UNESCO Portugal for Women in Science, BD Biosciences Immunology Grant.

\section{SUPPLEMENTARY MATERIAL}

The Supplementary Material for this article can be found online at: https://www.frontiersin.org/articles/10.3389/fncel. 2018.00277/full\#supplementary-material 


\section{REFERENCES}

Angelo, L. S., and Kurzrock, R. (2007). Vascular endothelial growth factor and its relationship to inflammatory mediators. Clin. Cancer Res. 13, 2825-2830. doi: 10.1158/1078-0432.CCR-06-2416

Arnold, T., and Betsholtz, C. (2013). The importance of microglia in the development of the vasculature in the central nervous system. Vasc. Cell 5, 4 . doi: 10.1186/2045-824X-5-4

Ashwal, S., Tone, B., Tian, H. R., Chong, S., and Obenaus, A. (2007). Comparison of two neonatal ischemic injury models using magnetic resonance imaging. Pediatr. Res. 61, 9-14. doi: 10.1203/01.pdr.0000251612.16069.4b

Back, S. A., Han, B. H., Luo, N. L., Chricton, C. A., Xanthoudakis, S., Tam, J., et al. (2002). Selective vulnerability of late oligodendrocyte progenitors to hypoxiaischemia. J. Neurosci. 22, 455-463. doi: 10.1523/JNEUROSCI.22-02-00455.2002

Back, S. A., Luo, N. L., Borenstein, N. S., Levine, J. M., Volpe, J. J., and Kinney, H. C. (2001). Late oligodendrocyte progenitors coincide with the developmental window of vulnerability for human perinatal white matter injury. J. Neurosci. 21, 1302-1312. doi: 10.1523/JNEUROSCI.21-04-01302.2001

Back, S. A., Riddle, A., and McClure, M. M. (2007). Maturation-dependent vulnerability of perinatal white matter in premature birth. Stroke $38,724-730$. doi: 10.1161/01.STR.0000254729.27386.05

Bae, S. H., Kong, T. H., Lee, H. S., Kim, K. S., Hong, K. S., Chopp, M., et al. (2012). Long-lasting paracrine effects of human cord blood cells on damaged neocortex in an animal model of cerebral palsy. Cell Transplant. 21, 2497-2515. doi: 10.3727/096368912X640457

Barone, F. C., Knudsen, D. J., Nelson, A., Feuerstein, G., and Willette, R. N. (1993). Mouse strain differences in susceptibility to cerebral ischemia are related to cerebral vascular anatomy. J. Cereb. Blood Flow Metab. 13, 683-692. doi: 10.1038/jcbfm.1993.87

Basu, A. P. (2014). Early intervention after perinatal stroke: opportunities and challenges. Dev. Med. Child. Neurol. 56, 516-521. doi: 10.1111/dmcn.12407

Buerki, S. E., Grandgirard, D., Datta, A. N., Hackenberg, A., Martin, F., SchmittMechelke, T., et al. (2016). Inflammatory markers in pediatric stroke: an attempt to better understanding the pathophysiology. Eur. J. Paediatr. Neurol. 20, 252-260. doi: 10.1016/j.ejpn.2015.12.006

Carmichael, S. T. (2005). Rodent models of focal stroke: size, mechanism, and purpose. NeuroRx 2, 396-409. doi: 10.1602/neurorx.2.3.396

Carreau, A., El Hafny-Rahbi, B., Matejuk, A., Grillon, C., and Kieda, C. (2011). Why is the partial oxygen pressure of human tissues a crucial parameter? Small molecules and hypoxia. J. Cell. Mol. Med. 15, 1239-1253. doi: 10.1111/j.1582-4934.2011.01258.x

Cnossen, M. H., van Ommen, C. H., and Appel, I. M. (2009). Etiology and treatment of perinatal stroke; a role for prothrombotic coagulation factors? Semin. Fetal Neonatal Med. 14, 311-317. doi: 10.1016/j.siny.2009.07.004

Del Duca, D., Wong, G., Trieu, P., Rodaros, D., Kouremenos, A., Tadevosyan, A., et al. (2009). Association of neonatal hypoxia with lasting changes in left ventricular gene expression: an animal model. J. Thorac. Cardiovasc. Surg. 138, 538-546.el. doi: 10.1016/j.jtcvs.2009.04.042

Deruelle, P., Balasubramaniam, V., Kunig, A. M., Seedorf, G. J., Markham, N. E., and Abman, S. H. (2006). BAY 41-2272, a direct activator of soluble guanylate cyclase, reduces right ventricular hypertrophy and prevents pulmonary vascular remodeling during chronic hypoxia in neonatal rats. Neonatology 90 , 135-144. doi: 10.1159/000092518

Dirnagl, U., Iadecola, C., and Moskowitz, M. A. (1999). Pathobiology of ischaemic stroke: an integrated view. Trends Neurosci. 22, 391-397. doi: 10.1016/S0166-2236(99)01401-0

Dunn, R., Queenan, B. N., Pak, D. T. S., and Forcelli, P. A. (2017). Divergent effects of levetiracetam and tiagabine against spontaneous seizures in adult rats following neonatal hypoxia. Epilepsy Res. 140, 1-7. doi: 10.1016/j.eplepsyres.2017.12.006

Faa, A., Iacovidou, N., Xanthos, T., Locci, A., Pampaloni, P., Aroni, F., et al. (2012). Hypoxia/reoxygenation-induced myocardial lesions in newborn piglets are related to interindividual variability and not to oxygen concentration. Clinics 67, 503-508. doi: 10.6061/clinics/2012(05)16

Fendt, M., Lex, A., Falkai, P., Henn, F., and Schmitt, A. (2008). Behavioural alterations in rats following neonatal hypoxia and effects of clozapine: implications for schizophrenia. Pharmacopsychiatry 41, 138-145. doi: $10.1055 / \mathrm{s}-2008-1058107$
Fernández-López, D., Faustino, J., Derugin, N., and Vexler, Z. S. (2013). Acute and chronic vascular responses to experimental focal arterial stroke in the neonate rat. Transl. Stroke Res. 4, 179-188. doi: 10.1007/s12975-012-0214-5

Fernández-López, D., Natarajan, N., Ashwal, S., and Vexler, Z. S. (2014). Mechanisms of perinatal arterial ischemic stroke. J. Cereb. Blood Flow Metab. 34, 921-932. doi: $10.1038 / \mathrm{jcbfm} .2014 .41$

Ferreira, R., Fonseca, M. C., Santos, T., Sargento-Freitas, J., Tjeng, R., Paiva, F., et al. (2016). Retinoic acid-loaded polymeric nanoparticles enhance vascular regulation of neural stem cell survival and differentiation after ischaemia. Nanoscale 8, 8126-8137. doi: 10.1039/C5NR09077F

Garberg, H. T., Solberg, R., Barlinn, J., Martinez-Orgado, J., Løberg, E.-M., and Saugstad, O. D. (2017). High-dose cannabidiol-induced hypotension after global hypoxia-ischemia in piglets. Neonatology 112, 143-149. doi: $10.1159 / 000471786$

Gersony, W. M., Morishima, H. O., Daniel, S. S., Kohl, S., Cohen, H., Brown, W., et al. (1976). The hemodynamic effects of intrauterine hypoxia: an experimental model in newborn lambs. J. Pediatr. 89, 631-635. doi: 10.1016/S0022-3476(76)80406-4

Girard, S., Kadhim, H., Beaudet, N., Sarret, P., and Sébire, G. (2009). Developmental motor deficits induced by combined fetal exposure to lipopolysaccharide and early neonatal hypoxia/ischemia: a novel animal model for cerebral palsy in very premature infants. Neuroscience 158, 673-682. doi: 10.1016/j.neuroscience.2008.10.032

Gonzalez, F. F., and Ferriero, D. M. (2009). Neuroprotection in the newborn infant. Clin. Perinatol. 36, 859-880, vii. doi: 10.1016/j.clp.2009.07.013

Govaert, P., Ramenghi, L., Taal, R., de Vries, L., and Deveber, G. (2009). Diagnosis of perinatal stroke I: definitions, differential diagnosis and registration. Acto Paediatr. 98, 1556-1567. doi: 10.1111/j.1651-2227.2009.01461.x

Gunny, R. S., and Lin, D. (2012). Imaging of perinatal stroke. Magn. Reson. Imaging Clin. N. Am. 20, 1-33. doi: 10.1016/j.mric.2011.10.001

Hagberg, H., Mallard, C., Ferriero, D. M., Vannucci, S. J., Levison, S. W., Vexler, Z. S., et al. (2015). The role of inflammation in perinatal brain injury. Nat. Rev. Neurol. 11, 192-208. doi: 10.1038/nrneurol.2015.13

Harbert, M. J., Tam, E. W., Glass, H. C., Bonifacio, S. L., Haeusslein, L. A., Barkovich, A. J., et al. (2011). Hypothermia is correlated with seizure absence in perinatal stroke. J. Child. Neurol. 26, 1126-1130. doi: $10.1177 / 0883073811408092$

Heyer, A., Hasselblatt, M., von Ahsen, N., Häfner, H., Sirén, A. L., and Ehrenreich, H. (2005). In vitro gender differences in neuronal survival on hypoxia and in 17beta-estradiol-mediated neuroprotection. J. Cereb. Blood Flow Metab. 25, 427-430. doi: 10.1038/sj.jcbfm.9600056

Jantzie, L. L., Cheung, P. Y., and Todd, K. G. (2005). Doxycycline reduces cleaved caspase-3 and microglial activation in an animal model of neonatal hypoxia-ischemia. J. Cereb. Blood Flow Metab. 25, 314-324. doi: $10.1038 /$ sj.jcbfm. 9600025

Jantzie, L. L., and Todd, K. G. (2010). Doxycycline inhibits proinflammatory cytokines but not acute cerebral cytogenesis after hypoxia-ischemia in neonatal rats. J. Psychiatry Neurosci. 35, 20. doi: 10.1503/jpn.090061

Jensen, F. (1995). An animal model of hypoxia-induced perinatal seizures. Ital. J. Neurol. Sci. 16, 59-68. doi: 10.1007/BF02229075

Johnston, M. V. (2005). Excitotoxicity in perinatal brain injury. Brain Pathol. 15, 234-240. doi: 10.1111/j.1750-3639.2005.tb00526.x

Kameda, S. R., Fukushiro, D. F., Wuo-Silva, R., Trombin, T. F., Procópio-Souza, R., Brandão, L. C., et al. (2013). Opposite effects of neonatal hypoxia on acute amphetamine-induced hyperlocomotion in adult and adolescent mice. Psychiatry Res. 208, 74-77. doi: 10.1016/j.psychres.2013.03.021

Kartal, Ö., Aydinöz, S., Kartal, A. T., Kelestemur, T., Caglayan, A. B., Beker, M. C., et al. (2016). Time dependent impact of perinatal hypoxia on growth hormone, insulin-like growth factor 1 and insulin-like growth factor binding protein-3. Metab. Brain Dis. 31, 827-835. doi: 10.1007/s11011-0169816-z

Kasdorf, E., and Perlman, J. M. (2013). Hyperthermia, inflammation, and perinatal brain injury. Pediatr. Neurol. 49, 8-14. doi: 10.1016/j.pediatrneurol.2012.12.026

Kichev, A., Rousset, C. I., Baburamani, A. A., Levison, S. W., Wood, T. L., Gressens, P., et al. (2014). Tumor necrosis factor-related apoptosis-inducing ligand (TRAIL) signaling and cell death in the immature central nervous system after hypoxia-ischemia and inflammation. J. Biol. Chem. 289, 9430-9439. doi: $10.1074 /$ jbc.M113.512350 
Kratzer, I., Chip, S., and Vexler, Z. S. (2014). Barrier mechanisms in neonatal stroke. Front. Neurosci. 8:359. doi: 10.3389/fnins.2014.00359

Kurnik, K., Kosch, A., Sträter, R., Schobess, R., Heller, C., Nowak-Göttl, U., et al. (2003). Recurrent thromboembolism in infants and children suffering from symptomatic neonatal arterial stroke: a prospective followup study. Stroke 34, 2887-2892. doi: 10.1161/01.STR.0000103745.03 393.39

Lafemina, M. J., Sheldon, R. A., and Ferriero, D. M. (2006). Acute hypoxia-ischemia results in hydrogen peroxide accumulation in neonatal but not adult mouse brain. Pediatr. Res. 59, 680-683. doi: 10.1203/01.pdr.0000214891.35363.6a

Lange, C., Storkebaum, E., de Almodóvar, C. R., Dewerchin, M., and Carmeliet, P. (2016). Vascular endothelial growth factor: a neurovascular target in neurological diseases. Nat. Rev. Neurol. 12, 439-454. doi: 10.1038/nrneurol.2016.88

Lee, H. S., Han, J., Bai, H. J., and Kim, K. W. (2009). Brain angiogenesis in developmental and pathological processes: regulation, molecular and cellular communication at the neurovascular interface. FEBS J. 276, 4622-4635. doi: 10.1111/j.1742-4658.2009.07174.x

Lee, J., Croen, L. A., Backstrand, K. H., Yoshida, C. K., Henning, L. H., Lindan, C., et al. (2005). Maternal and infant characteristics associated with perinatal arterial stroke in the infant. J. Am. Med. Assoc. 293, 723-729. doi: 10.1001/jama.293.6.723

Leonardo, C. C., Hall, A. A., Collier, L. A., Gottschall, P. E., and Pennypacker, K. R. (2009). Inhibition of gelatinase activity reduces neural injury in an ex vivo model of hypoxia-ischemia. Neuroscience 160, 755-766. doi: $10.1016 /$ j.neuroscience.2009.02.080

Leong, X. F., Ng, C. Y., and Jaarin, K. (2015). Animal models in cardiovascular research: hypertension and atherosclerosis. BioMed Res. Int. 2015, 528-757. doi: $10.1155 / 2015 / 528757$

Leviton, A., and Gressens, P. (2007). Neuronal damage accompanies perinatal white-matter damage. Trends Neurosci. 30, 473-478. doi: 10.1016/j.tins.2007.05.009

Li, H., Pin, S., Zeng, Z., Wang, M. M., Andreasson, K. A., and McCullough, L. D. (2005). Sex differences in cell death. Ann. Neurol. 58, 317-321. doi: 10.1002/ana.20538

Lubics, A., Reglodi, D., Tamás, A., Kiss, P., Szalai, M., Szalontay, L., et al. (2005). Neurological reflexes and early motor behavior in rats subjected to neonatal hypoxic-ischemic injury. Behav. Brain Res. 157, 157-165. doi: 10.1016/j.bbr.2004.06.019

Luhmann, H. J., Sinning, A., Yang, J. W., Reyes-Puerta, V., Stüttgen, M. C., Kirischuk, S., et al. (2016). Spontaneous neuronal activity in developing neocortical networks: from single cells to large-scale interactions. Front. Neural Circuits 10:40. doi: 10.3389/fncir.2016.00040

Machado, V., Pimentel, S., Pinto, F., and Nona, J. (2015). Perinatal ischemic stroke: a five-year retrospective study in a level-III maternity. Einstein 13, 65-71. doi: 10.1590/S1679-45082015AO3056

Machado-Pereira, M., Santos, T., Ferreira, L., Bernardino, L., and Ferreira, R. (2017). Anti-inflammatory strategy for M2 microglial polarization using retinoic acid-loaded nanoparticles. Mediators Inflamm. 2017, 6742427. doi: $10.1155 / 2017 / 6742427$

Machado-Pereira, M., Santos, T., Ferreira, L., Bernardino, L., and Ferreira, R. (2018). Intravenous administration of retinoic acid-loaded polymeric nanoparticles prevents ischemic injury in the immature brain. Neurosci. Lett. 673, 116-121. doi: 10.1016/j.neulet.2018.02.066

McQuillen, P. S., Sheldon, R. A., Shatz, C. J., and Ferriero, D. M. (2003). Selective vulnerability of subplate neurons after early neonatal hypoxiaischemia. J. Neurosci. 23, 3308-3315. doi: 10.1523/JNEUROSCI.23-08-0330 8.2003

Mirabelli-Badenier, M., Braunersreuther, V., Lenglet, S., Galan, K., Veneselli, E., Viviani, G. L., et al. (2012). Pathophysiological role of inflammatory molecules in paediatric ischaemic brain injury. Eur. J. Clin. Invest. 42, 784-794. doi: 10.1111/j.1365-2362.2012.02640.x

Nelson, K. B. (2007). Perinatal ischemic stroke. Stroke 38, 742-745. doi: 10.1161/01.STR.0000247921.97794.5e

Nelson, K. B., and Lynch, J. K. (2004). Stroke in newborn infants. Lancet Neurol. 3 , 150-158. doi: 10.1016/S1474-4422(04)00679-9
Ni, X., Yang, Z.-J., Carter, E. L., Martin, L. J., and Koehler, R. C. (2011). Striatal neuroprotection from neonatal hypoxia-ischemia in piglets by antioxidant treatment with EUK-134 or edaravone. Dev. Neurosci. 33, 299-311. doi: 10.1159/000327243

Rymo, S. F., Gerhardt, H., Sand, F. W., Lang, R., Uv, A., and Betsholtz, C. (2011). A two-way communication between microglial cells and angiogenic sprouts regulates angiogenesis in aortic ring cultures. PLOS ONE 6:e15846. doi: 10.1371/journal.pone.0015846

Schaeffer, E. L., Kühn, F., Schmitt, A., Gattaz, W. F., Gruber, O., SchneiderAxmann, T., et al. (2013). Increased cell proliferation in the rat anterior cingulate cortex following neonatal hypoxia: relevance to schizophrenia. J. Neural Transm. 120, 187-195. doi: 10.1007/s00702-0120859-y

Sengupta, P. (2013). The laboratory rat: relating its age with human's. Int. J. Prev. Med. 4, 624-630.

Sheldon, R. A., Chuai, J., and Ferriero, D. M. (1996). A rat model for hypoxicischemic brain damage in very premature infants. Neonatology 69, 327-341. doi: $10.1159 / 000244327$

Sheldon, R. A., Sedik, C., and Ferriero, D. M. (1998). Strain-related brain injury in neonatal mice subjected to hypoxia-ischemia. Brain Res. 810, 114-122. doi: 10.1016/S0006-8993(98)00892-0

Shen, Y., Plane, J. M., and Deng, W. (2010). Mouse models of periventricular leukomalacia. J. Vis. Exp. 39, 1951. doi: 10.3791/1951

Silverstein, F., and Johnston, M. V. (1984). Effects of hypoxia-ischemia on monoamine metabolism in the immature brain. Ann. Neurol. 15, 342-347. doi: 10.1002/ana.410150407

Slotkin, T. A., Lappi, S. E., McCook, E. C., Lorber, B. A., and Seidler, F. J. (1995). Loss of neonatal hypoxia tolerance after prenatal nicotine exposure: implications for sudden infant death syndrome. Brain Res. Bull. 38, 69-75. doi: 10.1016/0361-9230(95)00073-N

Sommer, C. J. (2017). Ischemic stroke: experimental models and reality. Acta Neuropathol. 133, 245-261. doi: 10.1007/s00401-017-1667-0

Stevens, J. P., Churchill, T., Fokkelman, K., Haase, E., Idikio, H., Korbutt, G., et al. (2008). Oxidative stress and matrix metalloproteinase-9 activity in the liver after hypoxia and reoxygenation with $21 \%$ or $100 \%$ oxygen in newborn piglets. Eur. J. Pharmacol. 580, 385-393. doi: 10.1016/j.ejphar.2007. 11.019

Suzuki, Y., Nagai, N., and Umemura, K. (2016). A review of the mechanisms of blood-brain barrier permeability by tissue-type plasminogen activator treatment for cerebral ischemia. Front. Cell Neurosci. 10:2. doi: $10.3389 /$ fncel.2016.00002

Tam, S. J., and Watts, R. J. (2010). Connecting vascular and nervous system development: angiogenesis and the blood-brain barrier. Annu. Rev. Neurosci. 33, 379-408. doi: 10.1146/annurev-neuro-060909-1 52829

Titomanlio, L., Fernández-López, D., Manganozzi, L., Moretti, R., Vexler, Z. S., and Gressens, P. (2015). Pathophysiology and neuroprotection of global and focal perinatal brain injury: lessons from animal models. Pediatr. Neurol. 52, 566-584. doi: 10.1016/j.pediatrneurol.2015. 01.016

Tornabene, E., and Brodin, B. (2016). Stroke and drug delivery-in vitro models of the ischemic blood-brain barrier. J. Pharma. Sci. 105, 398-405. doi: 10.1016/j.xphs.2015.11.041

Turtzo, L. C., and McCullough, L. D. (2010). Sex-specific responses to stroke. Fut. Neurol. 5, 47-59. doi: 10.2217/fnl.09.66

Vannucci, R. C., and Vannucci, S. J. (2005). Perinatal hypoxic-ischemic brain damage: evolution of an animal model. Dev. Neurosci. 27, 81-86. doi: $10.1159 / 000085978$

Vasudevan, A., and Bhide, P. G. (2008). Angiogenesis in the embryonic CNS: a new twist on an old tale. Cell Adh. Migr. 2, 167-169. doi: 10.4161/cam.2.3.6485

Vexler, Z. S., and Yenari, M. A. (2009). Does inflammation after stroke affect the developing brain differently than adult brain? Dev. Neurosci. 31, 378-393. doi: $10.1159 / 000232556$

Webber, D. J., Van Blitterswijk, M., and Chandran, S. (2009). Neuroprotective effect of oligodendrocyte precursor cell transplantation in a long-term model of periventricular leukomalacia. Am. J. Pathol. 175, 2332-2342. doi: 10.2353/ajpath.2009.090051 
Wolterink-Donselaar, I. G., Meerding, J. M., and Fernandes, C. (2009). A method for gender determination in newborn dark pigmented mice. Lab. Anim. 38, 35-38. doi: 10.1038/laban0109-35

Xu, G., Broadbelt, K. G., Haynes, R. L., Folkerth, R. D., Borenstein, N. S., Belliveau, R. A., et al. (2011). Late development of the GABAergic system in the human cerebral cortex and white matter. J. Neuropathol. Exp. Neurol. 70, 841-858. doi: 10.1097/NEN.0b013e31822f471c

Yu, L., Derrick, M., Ji, H., Silverman, R. B., Whitsett, J., Vásquez-Vivar, J., et al. (2011). Neuronal nitric oxide synthase inhibition prevents cerebral palsy following hypoxia-ischemia in fetal rabbits: comparison between JI-8 and 7-nitroindazole. Dev. Neurosci. 33, 312-319. doi: 10.1159/000327244
Conflict of Interest Statement: The authors declare that the research was conducted in the absence of any commercial or financial relationships that could be construed as a potential conflict of interest.

Copyright $\odot 2018$ Faustino-Mendes, Machado-Pereira, Castelo-Branco and Ferreira. This is an open-access article distributed under the terms of the Creative Commons Attribution License (CC BY). The use, distribution or reproduction in other forums is permitted, provided the original author(s) and the copyright owner(s) are credited and that the original publication in this journal is cited, in accordance with accepted academic practice. No use, distribution or reproduction is permitted which does not comply with these terms. 